\title{
EFFECTS OF HARVESTING ON LEAF PRODUCTION AND REPRODUCTIVE PERFORMANCE OF Copernicia prunifera (Mill.) H.E. Moore ${ }^{1}$
}

\author{
Irlaine Rodrigues Vieira ${ }^{2 *}$, Jefferson Soares de Oliveira ${ }^{3}$ e Maria Iracema Bezerra Loiola
}

\footnotetext{
${ }^{1}$ Recebido em 22.04.2014 aceito para publicação em 20.11.2015.

${ }^{2}$ Universidade Federal do Ceará, Programa de Pós-graduação em Desenvolvimento e Meio Ambiente, Fortaleza, CE - Brasil. E-mail: <irlaine.vieira@yahoo.com.br>.

${ }^{3}$ Universidade Federal do Piauí, Campus Ministro Reis Velloso, Departamento de Biomedicina, Parnaíba, PI - Brasil. Email:<jefsoliveira@ufpi.edu.br>.

${ }^{4}$ Universidade Federal do Ceará, Centro de Ciências, Departamento de Biologia, Laboratório Taxonomia de Angiospermas, Fortaleza, CE - Brasil. E-mail: <iloiola@yahoo.com.br>.

"Autor para correspondência.
}

\begin{abstract}
This work aimed to evaluate the consequences of the monthly extraction of immature leaves in survival, leaf production and reproductive performance of Copernicia prunifera $\mathrm{H}$. E. Moore palm, popularly known as carnaúba. One hundred sixty reproductive adult palms were monitored for 17 months in four extractive communities located at the coast of the state of Piauí. As a result, it was observed that leaves, flowers, fruits and seeds production were reduced in the palm submitted to $50 \%$ or $75 \%$ monthly extraction. Higher levels of extraction were followed by smaller levels in seed germination. No deaths were observed even in the group subjected to $75 \%$ monthly leaves exploration. In order not to produce damage to palm trees development it is suggested that leaf extraction rate should not exceed $25 \%$ monthly as well as pausing of extractive activity preferentially during fruit maturation.
\end{abstract}

Keywords: Traditional management; Environmental sustainability; Carnaúba.

\section{EFEITOS DO EXTRATIVISMO DE FOLHAS IMATURAS NA PERFORMANCE FOLIAR E REPRODUTIVA DE Copernicia prunifera (Mill.) H.E. Moore}

\begin{abstract}
RESUMO - Este trabalho objetivou avaliar as consequências da extração mensal de folhas imaturas sobre a sobrevivência, produção de folhas e desempenho reprodutivo da palmeira Copernicia prunifera H. E. Moore, popularmente conhecida como carnaúba. Cento e sessenta palmeiras reprodutivas adultas foram monitoradas por 17 meses em quatro comunidades extrativistas localizadas no litoral do Estado do Piaui. O resultado foi que a produção de folhas, flores, frutos e sementes diminuiu $50 \%$ e $75 \%$ em palmeiras submetidas à extração mensal das folhas imaturas. Elevados níveis de extração foram acompanhados por menores níveis de germinação de sementes. Não foram observadas mortes, mesmo no grupo submetido à extração mensal de folhas de $75 \%$. Para não causar danos ao desenvolvimento das palmeiras, sugerese um pousio, preferencialmente durante o periodo de maturação dos frutos, e que a taxa de extração mensal das folhas não exceda a $25 \%$.
\end{abstract}

Palavras-chave: Manejo tradicional; Sustentabilidade ambiental; Carnaúba. 


\section{INTRODUCTION}

Forest products are source of income for extractive communities (TICKTIN, 2004). The traditional extraction is usually sustainable and is based on popular knowledge about the ecology of exploited species (TICKTIN; JOHNS, 2002). However, this knowledge does not ensure that the extraction is performed in a sustainable manner. When forest products obtain economic valorization, there is often an intensification of extraction and consequently damage occurs to the exploited species (PERES et al., 2003; BOTHA et al., 2004).

One of the widely exploited forest products are the leaves of palm trees. Both expanded leaves (mature) and unexpanded (immature) are obtained for various uses (JOYAL, 1996; TICKTIN, 2004). Studies have reported that the extraction of mature leaves adult reproductive palms can adversely affect the production of their leaves and the reproductive performance, influencing the number of inflorescences of the plant and its fruits production (ENDRESS et al., 2004). However, there is a lack of information on the consequences of removing immature leaves palms (SAMPAIO et al., 2008). The extraction of immature leaves may have more severe consequences than the extraction of mature leaves in palm trees. In a study developed by Joyal (1996) in the Sabal uresana Trel palm, it was found that the rate of leaf production was decreased after the immature palm leaves were extracted, while the removal of mature leaves did not affect the palm development.

The immature leaves are extracted when fully formed, but not expanded. Consequently, these palms present deprived their photosynthetic capacity. Thus, removing immature leaves represents a subtraction of a structure that consume energy during it formation, without repair the photosynthetic cost of it production. On the contrary, the mature leaves enable the photosynthesis to happen and replaced to the palm tree the cost of carbon invested (JOYAL, 1996).

In the Northeastern of Brazil it is observed an expressive extraction of immature leaves of carnaúba palm (Copernicia prunifera H.E. Moore). During the dried months, the immature leaves are extracted to obtain carnauba wax and during the whole year the immature leaves are harvested for the handicrafts production (CARVALHO, 2008; IBGE, 2011).
The valorization of sustainable and ethnic products, the expansion of tourism, government support and the requalification of artisans promoted the expansion of commercial craft in Northeastern from Brazil, especially in state of Piauí (LAND INSTITUTE, 2011; SEBRAE, 2011). This increment lead to an intensification of the monthly extraction of immature leaves, which may have negative consequences on the development of vegetative and reproductive structures that are essential to reproduction and maintenance of species in the community (RATSIRARSON et al., 1996).

The present work aimed to understand the effects of the different extraction rate of immature leaves from Copernicia prunifera $\mathrm{H}$. E. Moore upon plant survival, vegetative and reproductive structures production and seed germination.

\section{MATERIALAND METHODS}

\subsection{Study area and specie description}

The study was conducted in four distinct sites located in extractive communities of Parnaíba city located on the coast of the state of Piauí, Brazil (2 ${ }^{\circ} 54^{\prime} 14.17$ “'S, $41^{\circ} 46$ ' 35.57 " W). This city has its history, economy and culture related to the extraction of carnaúba (DOMINGOS NETO, 2010). The climate is semi-arid, with average of annual rainfall and temperature of 965 $\mathrm{mm}$ and $27.9^{\circ} \mathrm{C}$, respectively (BASTOS et al., 2000). The types of vegetation found are mangroves, salt marshes, savannas and forest formations with presence of the carnaúba palm (ICMBIO, 2010).

The sites evaluated are located in the communities of Paraíso, Fazendinha, Alto do Pirão and Vazantinha (Table 1). These areas have similar abiotic factors of soil, moisture, temperature and light (JACOMINE et al., 1986; ANDRADE JÚNIOR et al., 2004). Each site was submitted to a specific regime of monthly extraction imposed by owners of areas (Table 1).

The Copernicia prunifera is a palm tree native from Brazil, living in alluvial clay soils of vegetation at semi-arid region of the Brazil (LORENZI, 1992; LEITMAN, 2012). It has a single stipe growing up to 15 meters tall and leaves are deeply divided halfway into segments, and are about one meter wide. Between leaves, numerous flowers are produced in inflorescences (LORENZI, 1992). Fruits present ovoid appearance, containing a single seed (LORENZI et al., 2004; BORÉM; 
Table 1 - Location of evaluated extractive communities and intensity of monthly extraction of immature leaves of carnaúba.

Tabela 1 - Localização das comunidades extrativistas avaliadas e intensidade de extração mensal de folhas imaturas de carnaúba.

\begin{tabular}{|c|c|c|}
\hline $\begin{array}{l}\text { Extractive } \\
\text { communities }\end{array}$ & Coordinates & $\begin{array}{c}\text { Intensity of } \\
\text { extraction } \\
(\%)\end{array}$ \\
\hline Vazantinha & 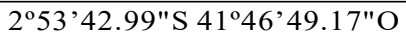 & 0 \\
\hline Paraíso & $2^{\circ} 53^{\prime} 40.92^{\prime \prime S} 41^{\circ} 46^{\prime} 57.59^{\prime \prime O}$ & 25 \\
\hline Fazendinha & $2^{\circ} 53^{\prime} 23.59^{\prime \prime S} 41^{\circ} 47^{\prime} 2.33^{\prime \prime O}$ & 50 \\
\hline Alto do Pirão & 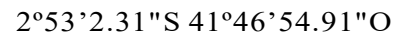 & 75 \\
\hline
\end{tabular}

MIRANDA, 2009). The plant plays an important social role and is locally titled "tree of life" because it has different uses. The leaves are source of wax, immature leaves are used to make crafts, fruits are used as meal, trunk are used to building houses and the roots in the folk medicine (D'ALVA, 2004).

\subsection{Experimental designs}

All the experimental design was performed from June 2011 to November 2012. One hundred sixty reproductive adult palms with an average 12 meters tall were selected in four extractive communities (Alto do Pirão, Fazendinha, Vazantinha, and Paraíso). Immature leaves were extracted monthly and the intensity of extraction (75\% Alto do Pirão, 50\% Fazendinha, 25\% Vazantinha and $0 \%$ Paraíso) was the same as traditionally performed by harvesters in each community. Palms from each of four areas (40 individuals per area) were evaluated by direct countingle af production, availability of mature leaves, number of inflorescences and number of floral branches containing immature, mature and aborted fruits. The palm flowers and fruits production per branch were estimated by counting 15 inflorescences and 15 floral branches containing immature fruits chosen randomly per area. The total seeds per branch were estimated taking into consideration that each fruit produces a single seed. The seeds were evaluated for length, width and biomass. Each half year, 15 inflorescences were collected per area and evaluated for length, number of rachilles and biomass. At the last month of the experiment, 50 mature leaves were collected from each site and evaluated for length, number of leaf segments and biomass.

\subsection{Seed germination}

Two hundred visually healthy seeds were collected in each studied area. These were placed in plastic tubes containing $500 \mathrm{ml}$ of water and incubated in BOD germination chamber with a $12 \mathrm{~h}$ light-dark cycle and at $27^{\circ} \mathrm{C}$. After 40 days, the number of germinated seeds was registered. The seed germination was considered positive when protrusion of the cotyledon petiole was seen (PINHEIRO, 1986).

\subsection{Data analysis}

In order to evaluate the production, length, number of leaf segments and biomass of leaves among different intensity of extraction, it was used the ANOVA followed by Kruskal-Wallis $(\mathrm{p}<0.05)$. The intensity extraction was correlated to production of inflorescences, biomass, number of rachilles and number of flowers per inflorescence through Spearman correlation (rs). The length of floral branches was performed through Pearson correlation $(r)$. In addition, the average of rs and $r$ were evaluated through ANOVA followed by Kruskal-Wallis $(\mathrm{p}<0.05)$. Fruit production was verified through ANOVA followed by Kruskal-Wallis $(\mathrm{p}<0.05)$ and seed germination thought ANOVA followed by Tukey test $(\mathrm{p}<0.01)$.

The influence of seasonality in the reproductive and vegetative structures production were analyzed using the correlation between the average monthly production and the corresponding month precipitation (data provided by the National Institute of Meteorology), using Pearson (r).

\section{RESULTS}

In the present study, it was observed that the monthly leaves production showed strongly influenced by the intensity of extraction ( $r s=-0.7142, p<0.0001)$. The palms that were not exploited $(0 \%)$ or exploited at $25 \%$ monthly intensity produced more leaves than those submitted to $50 \%$ or $75 \%$ of extraction (Table 2 ). Leaf structures were also affected by extractive activity. Palm subjected to intensity of $50 \%$ or $75 \%$ month extraction showed leaves with shorter length and biomass compared to control and $25 \%$ of extraction. Moreover, plants subjected to an extraction of $75 \%$ also showed a significant reduction in the number of leaf segments per leaf (Table 2).

The intensity of extraction was negatively correlated to the production of inflorescences $(r=-0.6215, \mathrm{p}<0.0001)$, length of the floral branches $(r=-0.4660, p=0.0002)$, the floral branches biomass ( $\mathrm{rs}=-0.8552, \mathrm{p}<0.0001)$, number of rachilles of floral branches ( $\mathrm{rs}=-0.7126$,

Revista Árvore, Viçosa-MG, v.40, n.1, p.117-123, 2016

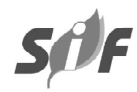


Table 2 - Production and structural alterations of leaves of palms submitted to different intensities of monthly extraction of immature leaves.

Tabela 2 - Produção e alterações estruturais de folhas de palmeiras submetidas a diferentes intensidades de extração mensal de folhas imaturas.

\begin{tabular}{ccccc}
\hline $\begin{array}{c}\text { Intensity of } \\
\text { extraction }\end{array}$ & $\begin{array}{c}\text { Leaf } \\
\text { production }\end{array}$ & $\begin{array}{c}\text { Leaf } \\
\text { segments }\end{array}$ & $\begin{array}{c}\text { Length } \\
(\mathrm{cm})\end{array}$ & $\begin{array}{c}\text { Biomass } \\
(\mathrm{g})\end{array}$ \\
\hline $0 \%$ & $5.30 \pm 0.58$ & $58.97 \pm 3.08$ & $82.82 \pm 6.2$ & $184.85 \pm 34.24$ \\
$25 \%$ & $4.56 \pm 1.44$ & $59.14 \pm 3.70$ & $82.62 \pm 5.82$ & $193.71 \pm 30.80$ \\
$50 \%$ & $3.27 \pm 0.84^{\mathrm{b}, \mathrm{c}}$ & $57.71 \pm 4.52$ & $78.97 \pm 6.92^{\mathrm{c}, \mathrm{d}}$ & $177.31 \pm 34.08^{\mathrm{d}}$ \\
$75 \%$ & $3.015 \pm 1.35^{\mathrm{a}, \mathrm{b}, \mathrm{c}}$ & $56.62 \pm 1.80^{\mathrm{a}, \mathrm{b}}$ & $69.74 \pm 4.90^{\mathrm{a}, \mathrm{b}}$ & $136.91 \pm 29 . \mathrm{b} 29^{\mathrm{a}, \mathrm{b}, \mathrm{e}}$ \\
\hline
\end{tabular}

Values are expressed as mean \pm SDof 40 plants, as analyzed by ANOVA followed by Kruskal-Wallis test (p<0.05). ${ }^{a} \mathrm{Compared}$ with $0 \%$ group; ${ }^{b}$ Compared with $25 \%$ group; ${ }^{\mathrm{c}} \mathrm{Compared}$ with $0 \%$ group; ${ }^{\mathrm{d}} \mathrm{Compared}$ with $25 \%$ group and; and ${ }^{\mathrm{e}} \mathrm{Compared}$ with $50 \%$ group.

$\mathrm{p}<0.0001)$, and the number of flowers per inflorescence ( $\mathrm{rs}=-0.8066, \mathrm{p}<0.0001)$. The number and length of inflorescences of unexploited palms were higher than those submitted to leaves extraction of $50 \%$ or $75 \%$ per month, but did not differ statistically from those that had $25 \%$ of leaves monthly exploited (Table 3 ). However, palm submitted to $25 \%$ exploration produced floral branches with less biomass when compared to control. This event was also observed at $50 \%$ or $75 \%$ intensity of extraction. The production of rachilles and flowers were also affected by extraction. Control palms $(0 \%)$ produced more rachilles and flowers than explored plants and no significant differences were observed in the production of these structures among harvested palms.
The number of floral branches containing immature and mature fruits was higher in control plants, however no statistical difference was observed compared to harvested groups (Table 4). On the other hand, fruits and seeds production reduced significantly at $25 \%$ extraction per month and it was not observed difference among plants subjected to $50 \%$ or $75 \%$ of exploration. Seeds from palms submitted to $75 \%$ extractive activity presented significant reduction on size and biomass (Table 4). In addition, the increment on intensity of exploration induced high rates of fruits abortions. It was also observed that the intensity of exploration influenced the percentage of germination of the seeds (Figure 1). At $75 \%$ of exploration seed germination reduced

Table 3 - Floral structure production of palms submitted to different intensities of monthly extraction of immature leaves. Tabela 3 - Produção de estruturas florais de palmeiras submetidas a diferentes intensidades de extração mensal de folhas imaturas.

\begin{tabular}{ccccc}
\hline $\begin{array}{c}\text { Intensity of } \\
\text { extraction }\end{array}$ & $\begin{array}{c}\text { Number of } \\
\text { inflorescences }\end{array}$ & $\begin{array}{c}\text { Floral branches } \\
\text { length }(\mathrm{cm})\end{array}$ & $\begin{array}{c}\text { Floral branches } \\
\text { biomass }(\mathrm{g})\end{array}$ & $\begin{array}{c}\text { Number of } \\
\text { rachilles }\end{array}$ \\
\hline $0 \%$ & $1.18 \pm 0.73$ & $2.50 \pm 0.40$ & $0.59 \pm 0.23$ & $1170.00 \pm 866.00$ \\
$25 \%$ & $0.83 \pm 0.47$ & $2.27 \pm 0.29^{\mathrm{f}}$ & $0.30 \pm 0.08^{\mathrm{f}}$ & $319.00 \pm 133.00^{\mathrm{f}}$ \\
$50 \%$ & $0.70 \pm 0.65^{\mathrm{d}, \mathrm{e}}$ & $2.06 \pm 0.45^{\mathrm{d}}$ & $0.17 \pm 0.09^{\mathrm{d}, \mathrm{e}}$ & $149.00 \pm 45.00^{\mathrm{d}}$ \\
$75 \%$ & $0.22 \pm 0.32^{\mathrm{a}, \mathrm{b}, \mathrm{c}}$ & $1.98 \pm 0.40^{\mathrm{b}}$ & $0.12 \pm 0.03^{\mathrm{f} g}$ & $155.00 \pm 74.00^{\mathrm{a}}$ \\
\hline
\end{tabular}

Values are expressed as mean \pm SD of 40 plants, as analyzed by ANOVA followed by Kruskal-Wallis test (p $<0.05$ ). ${ }^{a} \mathrm{Compared}$ with $0 \%$ group; ${ }^{\mathrm{b}}$ Compared with $25 \%$ group; ${ }^{\mathrm{c}} \mathrm{Compared}$ with $50 \%$ group; ${ }^{\mathrm{d}} \mathrm{Compared}$ with $0 \%$ group; ${ }^{\mathrm{e}} \mathrm{Compared}$ with $25 \%$ group; and ${ }^{\mathrm{f}} \mathrm{Compared}$ with $0 \%$ group.

Table 4 - Fruiting of palms submitted to different intensities of monthly extraction of immature leaves.

Tabela 4 - Frutificação de palmeiras submetidas a diferentes intensidades de extração mensal de folhas imaturas.

\begin{tabular}{|c|c|c|c|c|c|c|}
\hline $\begin{array}{l}\text { Intensity of } \\
\text { extraction }\end{array}$ & $\begin{array}{c}\text { Floral } \\
\text { branches containing } \\
\text { immature fruits }\end{array}$ & $\begin{array}{c}\text { Floral } \\
\text { branches containing } \\
\text { mature fruits }\end{array}$ & $\begin{array}{l}\text { Mature fruits } \\
\text { per cluster }\end{array}$ & $\begin{array}{l}\text { Seed size } \\
(\mathrm{cm})\end{array}$ & $\begin{array}{l}\text { Seed biomass } \\
\text { (g) }\end{array}$ & $\begin{array}{c}\text { Aborted } \\
\text { fruits (\%) }\end{array}$ \\
\hline 0 & $46+5360$ & 700 & & & & \\
\hline $25 \%$ & $92 \pm$ & 0 & & $4.40 \pm$ & 3.3 & $71.47^{\mathrm{f}}$ \\
\hline $50 \%$ & $54.46 \pm 42.50$ & $15.53 \pm 18.83$ & $25.20 \pm 25.00^{\mathrm{d}, \mathrm{e}}$ & $4.70 \pm 0.44^{\mathrm{d}}$ & $2.49 \pm 0.64^{\mathrm{e}}$ & $72.24^{\mathrm{d}, \mathrm{e}}$ \\
\hline $75 \%$ & $20.30 \pm 25.80^{\mathrm{a}}$ & $1.53 \pm 2.47^{\mathrm{b}}$ & $8.08 \pm 5.50^{\mathrm{a}, \mathrm{c}}$ & $4.00 \pm 0.50^{\mathrm{a}, \mathrm{b}, \mathrm{c}}$ & $2.98 \pm 0.70^{\mathrm{a}, \mathrm{b}, \mathrm{c}}$ & $92.42^{\mathrm{a}, \mathrm{b}, \mathrm{c}}$ \\
\hline
\end{tabular}

Values are expressed as mean $\pm \mathrm{SD}$ of 40 plants, as analyzed by ANOVA followed by Kruskal-Wallis test ( $\mathrm{p}<0.05)$. ${ }^{\mathrm{a}} \mathrm{Compared}$ with $0 \%$ group; ${ }^{\mathrm{b} C o m p a r e d ~ w i t h ~} 50 \%$ group; ${ }^{\mathrm{c} C}$ Compared with $25 \%$ group; ${ }^{\mathrm{d} C}$ Compared with $0 \%$ group; ${ }^{\mathrm{e}} \mathrm{Compared}$ with $25 \%$ group; and ${ }^{\mathrm{f}} \mathrm{Compared}$ with $0 \%$ group.

Revista Árvore, Viçosa-MG, v.40, n.1, p.117-123, 2016 


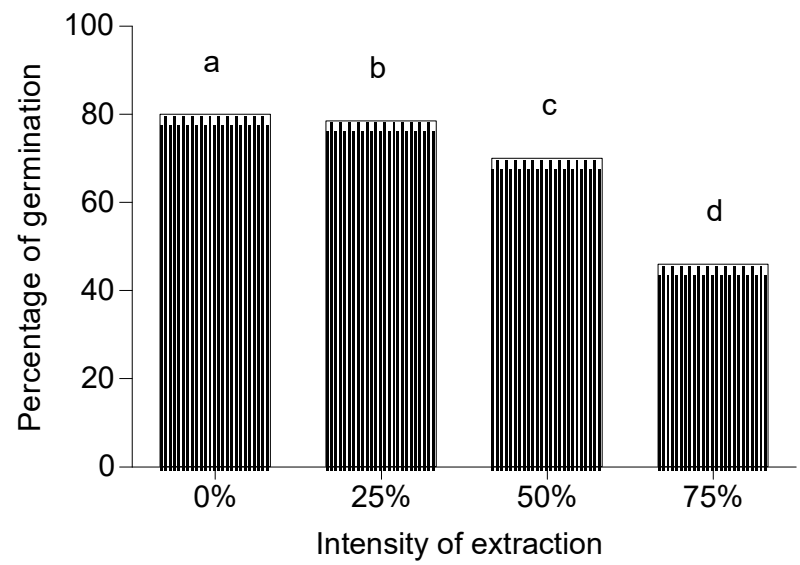

Figure 1 - Seed germination of carnaúba palms submitted to increasing intensities of monthly immature leaves extraction. Letters indicate significant differences among evaluated groups. ANOVA followed by Tukey test $(\mathrm{p}<0.01)$.

Figura 1-Germinação de sementes de carnaúbas submetidas a crescentes intensidades de extração mensal de folhas imaturas. As letras indicam diferenças significativas entre os grupos. ANOVA seguido pelo teste de Tukey $(p<0.01)$.

at about $42 \%$. In the present study, deaths were not reported among studied groups and none of evaluated parameter presented correlation to monthly precipitation $(\mathrm{rs}<0.00, \mathrm{p}>0.05)$.

\section{DISCUSSION}

The obtained data indicated that leaf production was impaired by extractive activity, except in palms exposed to $25 \%$ monthly exploration. The palms invest energy in the leaf production that will be refilled by photosynthesis process performed in the leaf. In the case of extraction of immature leaves, the process of photosynthesis should be compromised and the initial investment is not recovered. This event weaken palm and consequently reducing leaves production (JOYAL, 1996).

Besides of leaves production, the monthly extraction of leaves at a rate exceeding $50 \%$ affected negatively the length and biomass of leaves. These data corroborate to the effects observed in palms that had their mature leaves removed (RATSIRARSON et al., 1996; MCKEAN, 2003). The authors observed that the sizes of leaves were diminished significantly.

According to Obeso (1993), the ability of plants to compensate the loss of a structure depends on the resources available for replacement. In the present work, it was observed that plants submitted to extraction of $75 \%$ monthly showed insufficient amounts of leaves to keep the energetic demands of the palm. This observation was supported by reduction of leaf segments count per leaves and biomass of carnaúbas subject to this system of extraction (75\%). This event should occur because of low energy availability, as reflect of the intense exploitation.

The production of inflorescences, flowers and fruits in carnaúbas were also affected by extractive activity higher than $25 \%$ per month. When plants are submitted to energy shortage, as promoted by leaves extraction, it is common to observe reduction or reallocation of energy to produce some plant structures, such as flowers and fruits (KIGOMO et al., 1994; RATSIRASON et al., 1996; ENDRESS et al., 2004; HE etal., 2005). Similar observations were previously reported. Plant adjustments were observed in palms submitted to extraction of mature and immature leaves (FLOWERS;ASHTON, 2000; ENDRESS etal., 2004). Herein, we suggested that the strategies of reallocation of energy displayed by carnaúba changed according to the intensity of extraction. This hypothesis is reinforced by the observation that plants with extracted leaves at $25 \%$ per month maintained the total production and length of floral branches similar to control group ( $0 \%$ of extraction), although they had invested less energy in floral branches biomass, production of flowers and fruits. Moreover, at intensities of leaves extraction of $50 \%$ or $75 \%$, plants produced less flowers and fruits per cluster, generated shorter inflorescences concerning on length and biomass when compared to control.

The extraction of immature leaves induced significant reduction in total production and morphology of fruits. These effects may be associated to the fact of maintenance and development of fruits requires a high energy cost to the plant (KOZLOWSKY, 1971). Reducing the size of the fruit should be a mechanism to produce healthy fruits. However, this alteration may affect the percentage of seed germination. In the present work, it was observed that plants submitted to extractive activity produced lower seeds in size and biomass as well as less successful in germination. The increasing in seed fail germination may be related to malformed embryos commonly found in plants submitted to energy shortage (GRAY et al., 1986; CARVALHO; NAKAGAWA, 2012). These seeds present lower availability of nutritional reserves to embryo, making them potentially less vigorous.

Revista Árvore, Viçosa-MG, v.40, n.1, p.117-123, 2016 


\section{CONCLUSIONS}

Negative results were found in the extractive activity of reproductive adult palms leaves. It was observed that extraction of immature leaves at $50 \%$ or $75 \%$ per month promoted intense depletion of energy reserves observed by reduction of count, size and biomass of reproductive and vegetative structures of the carnaúba palm. In view of this, we suggest that a monthly leaves of extraction near to $25 \%$ should be respected in order to allow the palms refill their energy storage. It is suggested that pausing extractive activity should occurs preferentially during fruits maturation. This pausing period will help to conciliate environmental conservation and extraction activities.

\section{REFERENCES}

ANDRADE JR., A.S.; BASTOS, E.D.; SILVA, C.O.; GOMES, A.A.N.; FIGUEREDO JR., L.G.M. Atlas climatológico do estado do Piauí. Teresina: Embrapa, 2004. 151p. Disponível em: http://www.cpamn.embrapa.br/ publicacoes/documentos/2007/doc 167.pdf. Acesso em: 22 de set. 2012.

BASTOS, E.A.; RODRIGUES, B.H.N.; ANDRADE JR, A.S. Dados agrometeorológicos para município de Parnaíba, PI. (1990-1999). Teresina: Embrapa Meio-Norte, 2000. 27 p.

BORÉM, A.; MIRANDA, G.V. Melhoramento de plantas. 5.ed. Viçosa, MG: Universidade Federal de Viçosa, 2009. 529p.

BOTHA, J.; WITKOWSKI, E.T.F.; SHACKLETON, C.M. The impact of commercial harvesting on Warburgia salutaris ('pepperbark tree') in Mpumalanga, South Africa. Biodiversity and Conservation, v.13, n.9, p.1675-1698, 2004.

CARvalho, J.N.F. Pobreza e tecnologias sociais no extrativismo da carnaúba. 2008. 100f. Dissertação (Mestrado em Desenvolvimento e Meio Ambiente) Universidade Federal do Piauí, Teresina, 2008.

CARVAlho, N.M.; NAKAGAWA, J. Sementes: ciência, tecnologia e produção. 5.ed. Jaboticabal: FUNEP, 2012. 590p.

Revista Árvore, Viçosa-MG, v.40, n.1, p.117-123, 2016
D'AlVA, O.A. O extrativismo da carnaúba no Ceará. 2004. 193f. Dissertação (Mestrado em Desenvolvimento e Meio Ambiente) - Universidade Federal do Ceará, Fortaleza, 2004.

DOMINGOS NETO, M. O que os netos dos vaqueiros me contaram: o domínio oligárquico no Vale do Parnaíba. São Paulo: Annablume, 2010. 446p.

ENDRESS, B.A.; GORCHOV, D.L.; PETERSON, M.B.; SERRANO, E.P. Harvest of the palm Chamaedorea radicalis, its effects on leaf production, and implications for sustainable management. Conservation Biology, v. 18 , n.3, p.822-830, 2004.

FLORES, C.F.; ASHTON, P.M.S. Harvesting impact and economic value of Geonoma deversa, Arecaceae, an understorey palm used for roof thatching in the Peruvian Amazon. Economic Botany, v.54, n.3 p.267-277, 2000.

GRAY, D.; STECKEL, J.R.A.; WARD, J.A. The effect of cultivar and cultural factors on embryo sac volume and seed weight in carrot

(Daucuscarota L.). Annals of Botany, v.58, n.5, p.737-744, 1986.

HE, J.S.; BELLIN, K.S.W.; BAZZAZY, F.A. Leaflevel physiology, biomass, and reproduction of Phytolacca Americana under conditions of elevated $\mathrm{CO} 2$ and altered temperature regimes. International Journal of Plant Sciences, v.116, n.4, p.615-622, 2005.

\section{INSTITUTO BRASILEIRO DE GEOGRAFIA E} ESTATÍSTICA - IBGE. Produção da

Extração Vegetal e da Silvicultura. Rio de Janeiro: 2011.55p.

\section{INSTITUTO CHICO MENDES DE} CONSERVAÇÃO DA BIODIVERSIDADE- ICMBio. Ministério do Meio ambiente, 2010. Disponível em: http://www.icmbio.gov.br/portal/ images/stories/licitacoes/2010/4.PR\%2061\%20$\% 20$ Plano\%20de\%20Manejo\%20Parnaiba.pdf. Acesso em: 7 set. 2012.

INSTITUTO TERRA. Estudo exploratório da cadeia produtiva de artesanato no município de Aimorés- MG. Disponível 
em: http://www.institutoterra.org/doc/ 05_CADEIA_PRODUTIVA_ARTESANATO.PDF. Acesso em: 22 maio 2011.

JACOMINE, P.K.T.; CAVALCANTI, A.C.; PESSOA, S.C.P.; BURGOS, N.; MELO FILHO, H.F.R.; LOPES, O.F.; MEDEIROS, L.A.R.

Levantamento exploratórioreconhecimento de solos do Estado do Piauí. Rio de Janeiro: Embrapa/SNLCS/Sudene, 1986. 782p.

JOYAL, E. The palm has its time: an ethnoecology of Sabal uresana in Sonora, Mexico. Economic Botany, v.50, n.4, p.446-462, 1996.

KIGOMO, B.N.; WOODELL S.R.; SAVILL, P.S. Phenological pattern and some aspects of reproductive biology of Brachylaena huillensis O. Hoffm. African Journal of Ecology, v.32, n.4, p.296-307, 1994.

KOZLOWSKI, T.T. Growth and development of trees: Seed germination, ontogeny and shoot growth. New York: Academic Press, 1971. 514p.

LEITMAN, P.; SOARES, K.; HENDERSON, A.; NOBLICK, L.; MARTINS, R.C. Lista de Espécies da Flora do BrasilArecaceae. Disponível em: http:// floradobrasil.jbrj.gov.br/2012/ index tid $=15706 \&$ mode $=\mathrm{dp}$. Acesso em: 22 fev. 2012.

LORENZI, H. Árvores brasileiras: manual de identificação e cultivo de plantas arbóreas nativas do Brasil. São Paulo: Plantarum, 1992.

LORENZI, H.; SOUZA, H.M.; CERQUEIRA, L. S. C.; FERREIRA, E.; COSTA, J. T. M. Palmeiras brasileiras e exóticas cultivadas. São Paulo: Plantarum, 2004. 416p.

MCKEAN, S.G. toward sustainable use of palm leaves by a rural community in Kwazulu-natal,
South Africa. Economic Botany, v.57, n.1, p.65-72, 2003.

OBESO, J.R. Does defoliation affect reproductive output in herbaceous perennials and Woody plants in different ways? Functional Ecology, v.7, n.2, p.150-155, 1993.

PERES, C.A.; BAIDER, C.; ZUIDEMA, P.A.; WADT, L.H.O.; KAINER, K.A.; GOMES-SILVA, D.A.P.; SALOMÃO, R.P.; SIMÕES, L.L.; FRANCIOSI, E.R.N.; VALVERDE, F.C.; GRIBEL, R.; SHEPARD JR., G.H.; KANASHIRO, M.; COVENTRY, P.; YU, D.W.; WATKINSON, A.R.; FRECKLETON, R.P. Demographic threats to the sustainability of Brazil nut exploitation. Science, v.302, n.5653, p.2112-2114, 2003.

RATSIRARSON, J.; SILANDER, J.A.; RICHARD, A.F. Conservation and management of a Threatened Madagascar Palm Species, Neodypsis Decaryi, Jumelle. Conservation Biology, v.10, n.1, p.40-52, 1996.

SAMPAIO, M.B.; SCHMIDT, I.B.; FIGUEIREDO, I.B. Havesting effets and population ecology of buriti palm (Mauritia flexuosa L.f., Arecaceae) in the Jalapão region, central Brasil. Economic Botany, v.62, n.2, p.171-181, 2008.

SEBRAE. Programa Sebrae artesanato. Disponível em: http://www.sebrae.com.br/setor/ artesanato/sobre-artesanato/artesanato-no-sebrae. Acesso em: 9 abr. 2011.

PINHEIRO, C.H.B. Germinação de sementes de palmeiras. Revisão bibliográfica. Teresina: Embrapa, 1986. 102p.

TICKTIN, T. The ecological implications of harvesting non-timber forest products. Journal of Applied Ecology, v.41, n.1, p.11-21, 2004.

TICKTIN, T.; JOHNS, T. Chinanteco management of Aechmea magdalenae (Bromeliaceae): implications for incorporating TEK and TRM in management plans. Economic Botany, v.56, n.2, p.43-57, 2002.

Revista Árvore, Viçosa-MG, v.40, n.1, p.117-123, 2016 